\title{
THE PORTRAYAL OF POVERTY IN THE MAJOR NOVELS
}

\section{OF JOHN GALSWORTHY}

\section{BRIJESH KUMAR SHARMA}

Research Scholar, Department of English, University of Rajasthan, Jaipur, Rajasthan, India

John Galsworthy was a great British novelist, a dramatist, a journalist, an essayist, and a versatile genius. He made enough use of his literary devices as an efficacious vehicle, to raise the issues of social and moral reforms, especially, the liberation of the poor, the oppressed and the exploited sections of society. In the nineteenth century in Britain, the Industrial Revolution brought along various problems like unhealthy and unhygienic working conditions under which the labor had to work, a problem of child labor, poverty, low wages, etc. In such a dismal social ethos, Galsworthy rose to give an impassioned expression to the feeling of sorrow and pathos in his writing in general and novels in particular.
\end{abstract}

KEYWORDS: Victorian Era, Industrialization, Unemployment, Poverty, Starvation \& Revolt

Received: Sep 02, 2018; Accepted: Sep 22, 2018; Published: Nov 29, 2018; Paper Id.: IJELDEC201812

\section{INTRODUCTION}

Poverty means lack of basic amenities which make human life to live happily and effectively in society. It means not having food and fodder, huts and houses, shelters and stables. A poor hungry man is always jobless, helpless and homeless. He suffers from insecurity, weakness and a sense of alienation and thereby taking a course to violence and resistance. Poverty is one such stigma that has been prevalent in society from the time immemorial. The roots of poverty are very deep. From the time immemorial mankind has been fighting with this social problem but the results have not been satisfactory. The only difference is the intensity and the definition that has changed with the times. This social problem was very common in those days and due to the Industrial Revolution, the picture of the society simply transformed. It changed so much so that no one could have ever predicted that the repercussions of a revolution could be so deep and everlasting. It influenced each and every person in every possible way. There was no part of the society that remained unaffected by such social problems.

It was in the nineteenth century that John Galsworthy started writing, and it was the period which was highly influenced by industrialization. It was in the eighteenth century that the Industrial Revolution began in Britain and then subsequently it spread throughout Western Europe, North America, Japan, and eventually all over the world. The Industrial Revolution brought a big change in the socio-economic life the people. It had a profound effect on the social, economic and cultural conditions of the times. The important thing to be noticed here is that these effects were both positive and negative, but the problems to which industrialization gave birth were enormous. The problems which existed in the society in the eighteenth and the nineteenth centuries could easily be seen in the works of John Galsworthy. 


\section{ENGLAND: THE 19 ${ }^{\mathrm{TH}}$ CENTURY SCENARIO}

In the nineteenth century, introduction of machines affected the people directly and indirectly. This, on the one hand, provided ordinary working people with increased opportunities for employment in the new mills and factories, and on the contrary, it also created unemployment as the working men were replaced by efficient machines which obviously were more efficient and effective in the working and output as compared with the humans. Because of the increasing population, wages were reduced to the minimum. It created other problems of unemployment, housing, exploitation, corruption and resulted in some social evils.

In England, in the early twentieth century, $25 \%$ of the population of England was living below the poverty line. They were not able to read newspapers and they did not have a facility of public transport. It was like a nightmare that many people were very poor in the nineteenth century Britain. Before the twentieth century, extreme poverty was accepted as a harsh and hard reality of life. As a survey in 1914, cleared that $10 \%$ of people were living in extreme poverty. In Liverpool, in 1928, a survey described that $14 \%$ of the population was living at bare subsistence level. The surveys showed that the first and foremost reason for the poverty was low wages and in many cases the loss of the main breadwinner. If the only earner of the family was no more or ill or unemployed then it was a disaster for the family. Female members could get a job but they were paid much lower wages than men. Poor children often did not have the bare minimum clothes.

\section{A PORTRAYAL OF POVERTY BY JOHN GALSWORTHY}

John Galsworthy, a versatile genius, novelist and playwright lived between 1876 and 1933 and witnessed three eras in his lifetime: the Victorian Era (Queen Victoria, 1837-1901), the Edwardian era (King Edward VII, 1901-1910) and the Georgian Era (King George V, 1910-1936). The scenario which existed in the society in the eighteenth and the nineteenth centuries could easily be seen in the works of John Galsworthy. In his works, one can perfectly feel and understand the intensity of the problems that must have existed in those times in his works. In his best and most critically acclaimed work, The Forsyte Chronicles, we find the mention of the problem of poverty with a strong background and a thoughtful description of the problem. The first part of The Forsyte Chronicles does not contain much mention of the problem of poverty as the time in which it was written, the writer had not experienced these problems on the outer level, but in the second part i.e. A Modern Comedy, all the problems started to crop up gradually one after the other. As the title suggests, it is actually a modern comedy. In the context of the Industrial Revolution, the irony is that the machines were invented to help mankind, to make their life and living simpler, easier and more comfortable but on the contrary, this revolution made life cozy, comfortable and convenient just for the upper middle class and the elite class but the common men suffered a lot. The rich became richer and the poor, poorer. This is a paradox nevertheless true that the poor suffered and the rich enjoyed at their expense. Such is the picture of the modern comedy.

In Galsworthy's novel The White Monkey (1980), a couple, Bicket and his wife Victorine, are shown the victims of the problem of poverty. Bicket works in a company at a low salary. When his wife suffers from pneumonia, he gets involved in a theft due to which he is thrown out of his job. He finds it difficult to make both ends meet. He lives from hand to mouth. When Bicket goes to seek help from Mont who is one of the sympathetic characters in the novel, Bicket says to him, "You have no idea what pneumonia is like for the poor people"(p. 42) $)^{[1]}$. It's obvious from these words that in a situation wherein it's difficult to have two meals a day, a disease like pneumonia is a deadly dangerous disease and a disaster; it not only breaks one physically but also financially as the bread comes before medicine and one 
does not have money to buy either. In such a situation, getting trapped in a disease like pneumonia makes the conditions even worse. Keeping a bad health in itself is not good and on the other hand, keeping a bad health when one is without money is even worse. Only a poor man can understand the sensitivity and intensity of such a helpless and hopeless situation wherein the resources are not just limited, they are actually scarce and food and medicine are equally important for someone who is not well, not deciding what to buy from that money is a challenge in itself.

After the departure of Bicket, Mont thinks "How lucky they had been careful to have no baby" (p. 43), it's so clear from the thought that the state of poverty in those days was so intense that having a child was not an easy thing for a poor couple, as they could not support their own lives and having a baby meant more money to support him. A child brings along more and more responsibilities and in order to give the child a happy and healthy life, it becomes the duty of the parents that they meet out all such needs and be good parents to him. In fact, as the child grows, the needs also expand accordingly. And it is a vicious circle that does not end. Only money can break the circle called poverty. Poverty never leaves anyone easily.

Further, in the same novel, the problem of poverty is so acute that just earning a few pennies a day will not be sufficient for Bicket and Victorine. Hence, due to such circumstances, Victorine involves herself into a profession which a lady never opts for in a normal situation. It is only because a there is certain problem like poverty that makes her do all that she never thought of. But she is without any option and she has to compromise with the situation. Bicket gets involved in stealing in order to give his wife healthy food and medicines as she is suffering from pneumonia. Whereas, on the other hand, his wife Victorine, out of her concern for her husband who just to make both ends meet sells balloons on the roadside, agrees to become a nude subject for a painter in order to earn a meager amount of 60 dollars so that they may fly to Australia and move ahead in their lives, away from poverty and have a better start.Galsworthy himself wrote passionately about poverty from the beginning of his career to the very end. Just mark his reference to the living conditions in A Commentary (1908): "See the way the poor live-like pigs, crowded altogether; to anyone who knows, it's awful!'(pp. 4-5) ${ }^{[2]}$. Another example is from the short story Demos, in which there is a conversation between the narrator and a working-class man whose battered wife has run away with the children. The man speaks about his legal rights to his wife and children, the reason why he drinks and the fact that he cannot get a proper job. In the comment that the narrator gives, we see Galsworthy's preoccupation with the poor, so characteristic of his early work. Behind the figure of this man, he "seemed to see the countless masses of his fellows filing out of their dark streets, out of their alleys and foul lodgings, in a never-ending river of half-human flesh, with their faces set one way.”(p. 40) ${ }^{[3]}$

We know that Galsworthy saw London slums from very close quarters when he collected the rents for his father who owned some houses in London. Galsworthy has presented the same scene in many of his novels. In Fraternity (1995), he has given a description about Hilary Dallison's first visit to the Hound Street (a slum). The description of that street gave a very sad and sorrowful scene of the conditions wherein the poor had to live. Hilary and his little bulldog entered the Hound Street from its eastern end. It was a grey street of three-storied houses, all in one style of architecture. Further, he saw:

"Nearly all their doors were open, and on the doorsteps, babes and children were enjoying Easter holidays. They sat in apathy, varied by sudden little slaps and bursts of noise. Nearly all were dirty; some had whole boots, some half boots, and two or three had none. In the gutters more children were at play; their shrill tongues and febrile movements gave Hilary the feeling that their "caste" exacted of them a profession of this faith: To-day we live; to- 
morrow-if there be one-will be like today." $(p .32)^{[4]}$

The above reference drew that Galsworthy succeeded in drawing a clear picture of slums and its dwellers and the same scene usually we have seen near our surroundings. Further, passing through the street, when Hilary first entered the room of the model that he was employed as a translator for his father-in-law, he was overcome by nausea. There came on him a sickness, a sort of spiritual revolt, as he said:

"To live here, to pass up these stairs, between these dingy, bilious walls, on this dirty carpet, with this-ugh! He then realizes that there is an unbridgeable gap between him and the class he represents and their 'shadows' in the slums. They see their 'shadows' in the streets, in factories as people doing odd-jobs for them, but do not see them as "human beings possessing the same faculties and passions." (p. 33)

Truly, Galsworthy himself felt a large gap between the existence of his rich class and the poor class, when he saw the poor people of slums. In the same way, in the Hound Street, in front of a slum building, from a conversation between a butler Mr. Creed (a slum dweller) and Hilary, Galsworthy made it clear that the poor stayed in the worst living conditions and the rich only aimed at making more and more money out of their plight. It was their peculiar destiny to live a life of the poor. In the slum, houses were as small as the compartment of railways. Landlords cared only for rent. Hilary asks Mr. Creed about the street where he lives in then Mr. Creed replies:

“These little 'houses, they get into the hands o' little men, and they don't care so long as they make their rent out $o$ ' them. They can't help themselves-lowclass o' man like that; 'e's got to do the best 'e can for 'himself. They say there's thousands $o$ ' these 'houses all over London. There's some that's for pullin' of 'em down, but that's talkin' rubbish; where are you goin' to get the money to do it? These 'ere little men, they can't afford even to put a paper on the walls, and the big ground landlords-you can't expect them to know what's happen in' behind their backs. ”( . 36)

Further, in the same novel, from the conversation between Cecilia and Hilary, the poor condition of the Hound Street and its dwellers came into light, as Cecilia says:

"The people who lived there, poor downtrodden things, had enough to do to keep themselves alive. They were in the air; their condition was deplorable! Could a person whose condition was deplorable find time or strength for any sort of lurid exhibition such as this? It was incredible.”(p. 50)

Once, Thyme Dallsion, the daughter of Cecilia, visited the Hound Street and the way she described her uncle Hilary Dallison about the condition of the slum also brought forth the state of the poor and also the attitude of the rich towards them. From this example, Galsworthy tried to make it clear that the rich had a callous and cruel attitude towards the sufferings of the poor:

"I hate these slums, uncle; they're so disgusting! I believe we simply make the difficulties ourselves by seeing them." (p. 83)

According to the narrator, the rich simply did not and could not know the poor. The reason for this was a matter of the senses. The rich never felt the curse of poverty but on the other hand, poverty was the part and parcel of the poor. It is very much clear in Galsworthy's novel through the words of the narrator when he says:

"They knew that whatever money they might give, or time devote, their hearts could never open, unless-unless they closed their ears, and eyes and noses." (p. 88) 
In the same novel, the description of an old man (Mr. Creed) selling the newspaper in the street by Mrs. Stephen Dallision, shows how his illness swallows all his earnings. He watches her (Mrs. Stephen Dallision) with special interest, not, indeed, attempting to attract attention, though conscious in every fiber that he has only sold five copies of his early issues. The narrator tells about Mr. Creed thus:

"In fact, before life threw him into the streets, by giving him a disease in curing which his savings had disappeared, he had been a butler...”(p. 4)

There are various other instances in the novel Fraternity that describe the poor and their pathetic state in society. Food is a necessary item to get strength and energy to work but if she/he doesn't have this, it makes him/her weak in health. In Fraternity, we find the most pathetic condition of a girl (Ivy Barton) who comes in the city to find a job as a model, but she fails in it, and many times, she works with an empty belly and faints on the working site as Mrs. Tallents Smallpeace tells Cecilia about Ivy Barton:

“That's your sister's picture, 'The Shadow,' they're looking at, isn't it?" asked Mrs. Tallents Smallpeace. "I remember seeing it on Christmas Day, and the little model who was sitting for it-an attractive type! Your brother-in-law told me how interested you all were in her. Quite a romantic story, wasn't it, about her fainting from want of food when she first came to sit?" (p. 8)

This instance shows the plight of the poor in the contemporary times of Galsworthy. They did not even have resources to make their two ends meet. With the result, they had to accept whatever job opportunities were offered to them, in order to earn their living. England had been a world power but in that powerful country, many people had an incurable problem such as poverty. People were very much attracted by the city life because it meant greater opportunities of the job, but when they came to pursue it then they found that they were better in their village.

In the same novel, when Hilary and his father-in-law Mr. Stone went for a walk, then they came across the poor conditions that prevailed in London. In the novel, the narrator describes the scene as:

"These were their happy hunting-grounds, and here they came each day to watch from a safe distance the little dirty girls sitting on the grass nursing little dirty boys, to listen to the ceaseless chatter of these common urchins, and learn to deal with the great problem of the lowest classes." (p. 29)

In another instance, when Hilary chases Mr. Hughs, then on the way, the poor condition of London comes into the picture:

"In the center of the lane, a row of elm-trees displayed their gnarled, knotted roots. Human beings were seated there, whose matted hair clung round their tired faces. Their gaunt limbs were clothed in rags; each had a stick, and some sort of dirty bundle tied to it. They were asleep. On a bench beyond, two toothless old women sat, moving their eyes from side to side, and a crimson-faced woman was snoring. Under the next tree a Cockney youth and his girl were sitting side by side-pale young things, with loose mouths, and hollow cheeks, and restless eyes. Their arms were enlaced; they were silent. A little farther on two young men in working clothes were looking straight before them, with desperately tired faces. They, too, were silent.”(p. 55)

In the writing of Galsworthy, description of poverty and the intensity of social evil do not end only with these instances. With the progression of the novel, more and more instances mentioning the conditions of the poor in society 
come across. In a conversation between Ivy (the little model) and Hilary, she mentions about her earnings and expenditure which makes her living possible. She gets two shillings a day from Mr. Stone, and it is very hard for her to live a respectable life with these shillings:

"Three and sixpence for my rent, and breakfast costs three pence nearly-only bread-and-butter-that's five and two; and washing's always at least ten pence-that's six; and little things last week was a shilling-even when I don't take buses-seven; that leaves five shillings for my dinners. Mr. Stone always gives me tea. It's my clothes worries me. My hat is awful, and I do want some--I do wish I was rich.”(p56)

Poverty preys upon everyone and it doesn't make any difference between the old and the young. A very deplorable condition of a mother and her child comes in the novel, Fraternity. The death of Mrs. Hughs' baby due to insufficient feeding describes the depth of this social problem (poverty) which leads the baby to death. Martin, a doctor who comes to see Mrs. Hughs and asks her, "When did you feed the baby last?" At this she says:

"About half-past six last evening sir. It slept all night; but today, of course, I've been all torn to pieces; my milk's gone. I've tried it with the bottle, but it wouldn't take it."'(p. 129)

Martin bends down to the baby's face and puts his finger on its chin; bending lower yet, he raises the eyelid of the tiny eye then he declares that the baby is dead. The narrator shows the pathetic condition of the wretched mother, when she hears the word "dead":

"At the word "dead" Mrs. Hughs, stooping behind him, snatched the baby to her throat. With its drooping head close to her, she clutched and rocked it without sound. Full five minutes this desperate mute struggle with eternal silence lasted -the feeling, and warming, and breathing on the little limbs. Then, sitting down, bent almost double over her baby, she moaned." (p. 129)

It was one of the cruelest aspects of prevailing poverty in society of that time as presented by Galsworthy. On the one hand, elite society was becoming better and better, but on the other hand, infants and children were dying due to insufficient feeding. There are many instances in the novel wherein we find the characters discussing the social issues like poverty. It is very clear from the references that the problem of poverty was very prominent in the society at that time, and needed quick attention by the government. We just find the mention and lots of discussion on this social issue with various suggestions to solve such problems but till the end there is no solution to the problem, the issue stays right there in the end as well. This is quite a real scenario as when the problem arises, we have people from intellectual classes brooding over it, holding discussions on it now and then, but the problem stays very much there with no core solution to it and this process goes on and on.

In another novel, The Freeland (1925), the condition of three small children, Billy, Susie and Biddy whose father is in imprisonment for putting on fire the hay that belongs to Lady Mallorings, shows their struggle with their fate and poverty. The little children are homeless because they are compelled by the landlord of the house to vacate the house. One of the little trysts tells Frances Freeland about the pathetic conditions of life:

“That's where Billy sleeps, Susie sleeps here, and I sleep there; and our father sleeped in here before he went to prison." ${ }^{[5]}($ p. 202) 
Then another little child says:

“We like bein' here; we hope Father won't be comin' back from prison for a long time, so as we can go on stayin' here. Mr. Freeland gives us apples. Once we had a shillin', and we were sick. We're goin' to spend three pennies out of one shillin' every day, till they're gone.”(p. 202)

In the nineteenth century British society, poverty was not only limited to the city but it created havoc in the life of the poor simple innocent villagers who toiled and moiled day and night. In The Freeland, a conversation between the two cousins Derek and Alan, highlights the condition of the people living in a village Joyfield. These are not urban people but they are simple rustics. Alan suggests Derek leave the path of rebellion for the welfare of the laborers, and then Derek breaks out and says:

"Walk through this country as we've walked; see the pigsties the people live in; see the water they drink; see the tiny patches of ground they have; see the way their roofs let in the rain; see their peeky children; see their patience and their hopelessness; see them working day in and day out, and coming on the parish at the end! See all that, and then talk about reason! Reason! It's the coward's excuse, and the rich man's excuse, for doing nothing. It's the excuse of the man who takes jolly good care not to see for fear that he may come to feel! Reason never does anything, it's too reasonable." (p. 55)

In Fraternity and The Freeland, Galsworthy presented many references related to poverty and its effect on the poor people but these references are not only limited to these two novels, but they continue in many other novels. In The Country House (1930), one of the female characters, Margery Pendyce comes out for a walk and then she thinks about the city and its dwellers. This highlights the conditions of the poverty in the cities of England at that time:

"From a little back slum, within a stone's throw of the god of the Stoics' Club, there had come out two seamstresses to take the air; one was in consumption, having neglected to earn enough to feed herself properly for some years past, and the other looked as if she would be in consumption shortly, for the same reason. They stood on the pavement, watching the cabs drive up. Some of the Stoics saw them and thought: 'Poor girls! they look awfully bad.' Three or four said to themselves: "It oughtn't to be allowed. I mean, it's so painful to see; and it's not as if one could do anything. They're not beggars, don't you know, and so what can one do?" $(p .170)^{[6]}$

In the same way, in the novel, The Man of Property (1930), Galsworthy once again throws light on poverty and shows how the rich take benefit of the poor. The rich always weigh the poor in the balance of money. Soames gets married to Irene because she is very poor and he encashes her pathetic poor plight. He knows very well that his status and richness in society would compel her step-mother to allow Irene to stay with him. When Soames sees Irene very first time in his life, then he enquires about her to his friend. At this, his friend informs him that she is a poor girl with no money. As soon as Soames hears the word "poor", he becomes sure about his victory over the lady. Soames recalls his friend's first introduction about Irene:

“That-oh! Irene Heron. Her father, Professor Heron, died this year. She lives with her stepmother. She's a nice girl, a pretty girl, but no money!" $(p .100)^{[7]}$

Further, in the same novel, Soames files a case against a poor architect Philip, when he (Soames) comes to know about his (Philip's) affair with his wife. Soames knows very well that Philip will not be able to survive in the lawsuit as he (Philip) is not rich like him (Soames) but a blooming and poor architect. Philip's aunt Mrs. Baynes tells June (the fiancée 
of Philip) about the poor condition of Philip:

“It's very dreadful for him, you know-he's got no money-he's very hard up. And we can't help him, I'm sure. I'm told the money-lenders won't lend if you have no security, and he has none-none at all.”(p. 228)

In the nineteenth century, England was the world power and she was also enjoying the fruit of industrialization. The pelf, prosperity, and power of England attracted so many people from the distant corners of the country to try their luck. In this pursuit, many people came to England but they failed badly. They were not aware of the prevailing poverty in the society of England. They didn't imagine ever that a powerful country like England might be a victim of poverty. Galsworthy mentioned this point very well in his works. In the novel, The Island Pharisees (1908), there was a character Louis Ferrand who came to England to make his fortune but he failed miserably in finding a work. He had lost all his money in search of a job, and finally, he got too poor to take his two-time meal. He said about his struggling to one of his friends, Richard Shelton who always helped him in his hard times:

"I 'm living on porridge now; splendid stuff for making bone. I generally live on porridge for a week at the end of every month. It's the best diet if you're hard up." $(p .72)^{[8]}$

In Villa Rubein (1933), we find the presentation of poverty at its extreme level. In the novel, there was a painter Alois Harz. Earlier in his youth and struggling years, he suffered the curse of poverty. He joined a group of youths who were also poor and they earned their livelihood anyhow. Their poor conditions filled their hearts with bitterness and grudge against society. According to Alois, "It's a crime not to have been born a gentleman. (p. 51) ${ }^{[9]}$

In his life, he spent most of his days on the mercy of others. When he told her lover, Christian, about his struggling days, by this we come to know about the mental status of the poor man who does not hesitate to be helped by the other:

"What do you want me to tell you? How I went twice a week to eat free dinners! How I took charity! How I was hungry! There was a rich cousin of my mother's - I used to go to him. I didn't like it. But if you're starving in the winter. I used to borrow apronsful of coals from other students who were as poor-but I never went to the rich students."(p. 53)

\section{CONCLUSIONS}

Finally, we find that John Galsworthy has presented this issue of poverty with sensitivity, dealing with the theme of poverty in his works. He felt the problem of poverty in his contemporary society and discussed it in his works. Poverty had been a major problem for the societies of all the countries. Nobody could imagine the presence of poverty in the rich British society. It was a hidden aspect of British society but it was revealed by Galsworthy very well in his novels.

\section{REFERENCES}

1. Galsworthy, John.(1980).The White Monkey. London: Penguin Books.

2. Galsworthy, John. (1928).Satires and A Commentary. London: Heinemann.

3. Galsworthy, John. (1928).Demos. London: Heinemann.

4. Galsworthy, John. (1995).Fraternity. New York: Caroll \& Graf Publishers.

5. Galsworthy, John. (1927).The Freeland. London: Heinemann.

6. Galsworthy, John. (1930).The Country House. London: Heinemann. 
7. Galsworthy, John. (1973). The Man of Property. London: Penguin Books.

8. Galsworthy, John. (1908). The Island Pharisees. London: Heinemann.

9. Galsworthy, John. (John Sinjohn, pseudonym). (1933). Villa Rubein. London: Heinemann. 
